\title{
Slaughter and Carcass Traits of Geese with Different Feather Colour and Gender
}

\section{-Author(s)}

Kırmızıbayrak T' (D) https://orcid.org/0000-0003-3626-6137 Kuru Boğa B" (D) https://orcid.org/0000-0002-7170-270X

Department of Animal Breeding and Husbandry, Faculty of Veterinary Medicine, Kafkas University, Kars, Turkey.

" Department of Animal Breeding and Husbandry, Faculty of Veterinary Medicine, Kafkas University, Paşaçayırı Campus, Kars 36100, Turkey.

*This article was presented as a poster in 3rdVETIstanbul Group Congress, 17-20 May 2016, Sarajevo, Bosnia and Herzegovina.

\section{-Mail Address}

Corresponding author e-mail address Buket Boğa Kuru

Department of Animal Breeding and Husbandry,Faculty of Veterinary Medicine, Kafkas University, Paşaçayııı Campus, 36100, Kars, Turkey.

Phone: +90 4742426807 / 5115

Email: buket_vetfak @hotmail.com

\section{EKeywords}

Carcass trait, feather colour, geese, gender, slaughter trait.

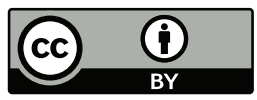

Submitted: 24/February/2018 Approved: 16/July/2018

\section{ABSTRACT}

The aim of this study was to determine slaughter and carcass traits of geese with different feather colour and gender. The study was conducted with Turkish geese in free-range production conditions in Kars, Turkey. A total of 282 geese ( 251 females, 31 males) were grouped by feather colour as black $(n=49)$, white $(n=77)$, black pied $(n=127)$, and brown and brown tawny $(n=29)$. Geese were weighed before slaughter and then the slaughter and carcass traits were determined. Data were subjected to one-way ANOVA, and post-hoc Tukey HSD test was applied to compare feather-colour means and the independent sample $t$-test was used to compare gender means. Feather colour did not influence ( $p>0.05)$ slaughter and carcass traits, except for hot carcass, feather and heart percentages $(p<0.05)$. Males showed statistically higher feet $(p<0.001)$, heart $(p<0.01)$, liver $(p<0.05)$ and gizzard $(p<0.01)$ weights compared with females, as well as significantly higher $(p<0.05)$ feet, heart, liver and gizzard yields. In conclusion, feather colour did not influence the evaluated slaughter and carcass characteristics of geese reared under semi-intensive conditions in the province of Kars, Turkey, and higher feet, heart, liver and gizzard weights and yields were obtained in males than in females.

\section{INTRODUCTION}

Turkish commercial poultry production is based, a very large extent, on hybrid broiler production. As to the production of other poultry, turkeys are more prevalent than geese in Turkey (Tuik, 2016). Globally, however, Turkey has an important goose flock. It is the $13^{\text {th }}$ country in the number of geese, accounting for $0.28 \%$ of the world's geese flock (Fao, 2014). In addition, geese represent $0.12 \%$ of Turkey's total number of poultry. The province of Kars is the main region of intensive goose production in Turkey. According to the data of the year 2016, about 30\% of Turkey's goose flocks are reared in that province (Tuik, 2016).

Kars and its surroundings have suitable climate and natural pasture conditions for goose breeding. These advantageous conditions are utilized in a highly efficient manner by smallholder farms, which considerably reduced production costs (Kırmızıbayrak, 2001; 2002; Demir et al., 2013). In addition to meeting their own nutritional needs, smallholder farms that produce geese provide additional income for households with the sales of goose meat, edible organs, and feathers (Kırmızıbayrak, 2001; Demir et al., 2013; Kırmızıbayrak et al., 2016a).

Today, there is a growing demand for food products obtained by organic production systems, in particular for organic poultry products. The meat quality of local poultry breeds produced under traditional conditions on commercial farms are highly valued by the consumers 
(Castellini et al., 2008; Kırmızıbayrak et al., 2011). Almost all geese in Kars and its surroundings are produced in extensive or semi-extensive conditions, and as close as possible to organic conditions (Kırmızıbayrak et al., 2011).

This study was carried out to determine the effects of different feather colours and gender on selected slaughter and carcass characteristics of geese reared in semi-intensive conditions in the province of Kars, which is the main goose-producing region of Turkey.

\section{MATERIALS AND METHODS}

\section{Location of the study}

This study was carried out in October 2015 in the province of Kars, where native Turkish geese are produced. The area where the study was carried out is located at $1751 \mathrm{~m}$ altitude, and at the GPS coordinates 40'32'5.4240" North and 42 59'38.1228" East. Geese are produced in a pasture area where the Kars stream passes through, and housed in a tent on the same area.

\section{Birds and feeding}

This study was carried out with Turkish geese reared on a commercial farm under free-range production conditions. Clinically healthy 8-10 month old 282 geese were used. The geese were grouped into black $(n=49)$, white $(n=77)$, black pied $(n=127)$, and brown and brown tawny $(n=29)$ according to their feather body colour. According to the gender, 251 female and 31 male geese were investigated.

The geese were reared on pastures until slaughter. During the daytime, the geese were grazed freely as a flock on the pasture, and were housed in the tent when returning from the pasture. In addition to the pasture, geese were supplied with soaked barley at $150 \mathrm{~g} / \mathrm{head}$. Water was provided to the geese ad libitum.

\section{Slaughter and carcass characteristics}

The geese were not allowed to graze and did not receive additional feeding for $12 \mathrm{~h}$ before slaughtering, but water continued to be supplied until slaughter. All geese were numbered prior to slaughter and their slaughter weights were measured on a digital scale with a precision of $0.1 \mathrm{~g}$.

The geese were sacrificed by severing their necks. After blood flow ceased, birds were weighed again to calculate blood weight. Carcasses were immersed in water at $60^{\circ} \mathrm{C}$ for $5 \mathrm{~min}$, after which the feathers were removed. Feather weight was calculated as by weighing the carcasses after feathers were removed. Head and feet were removed and weighed separetely. Internal organs were removed and hot carcass, heart, liver, gizzard and intestine weights were measured. Carcass yield, and blood, feather, head, feet, liver, heart, gizzard, intestines and abdominal fat relative weights are calculated as a percentage of live weight at slaughter.

\section{Statistical analysis}

Slaughter and carcass data were subjected to oneway analysis of variance. Mean results of feather colour groups were compared by post-hoc Tukey HSD test, and gender results by the independent sample t-test. Statistical analyses were performed by using the SPSS ${ }^{\circledR} 18.0$ software (SPSS Inc., Chicago, IL, USA) program. The data in the study were given as mean $(\bar{X})$ \pm standard error of mean $(S \bar{X})$.

\section{RESULTS}

The mean $\pm S \bar{X}$ of the evaluated slaughter and carcass characteristics, according to feather colour and gender is given in Table 1, and yield values relative to slaughter weight (percentages) are shown in Table 2.

Slaughter weights of $3786.31 \pm 46.01,3732.43$ $\pm 33.85,3759.89 \pm 23.97,3797.28 \pm 51.00 \mathrm{~g}$ were determined for black, white, black pied and brown/ brown tawny groups, respectively $(p=0.659)$. No statistically significant slaughter and carcass weight differences were detected among the different feather colour groups ( $p>0.05$ ).

Goose gender influenced some carcass characteristics. The weights of the feet $(p<0.001)$, heart $(p<0.01)$, liver $(p<0.05)$ and gizzard $(p<0.01)$ of the male geese were statistically higher compared to those of females (Table 1).

Hot carcass yield, feather yield and heart yield were significantly different $(p<0.05)$ among feather colour groups. Statistically higher feet $(p<0.01)$, heart $(p<0.05)$, liver $(p<0.05)$ and gizzard $(p<0.05)$ yields were also determined in male than in female geese (Table 2).

\section{DISCUSSION}

In the present study, the overall average slaughter weight was $3760 \mathrm{~g}$, with average values of $3823 \mathrm{~g}$ in males and $3753 \mathrm{~g}$ in females. These findings are closely similar with a previous study with geese conducted in the province of Kars (Kırmızıbayrak et al., 2011), which reported average slaughter weights of $3572 \mathrm{~g}$ at 6-8 


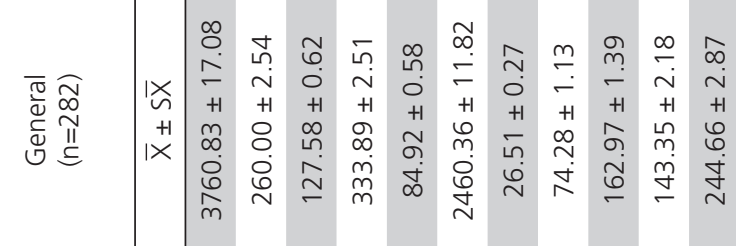

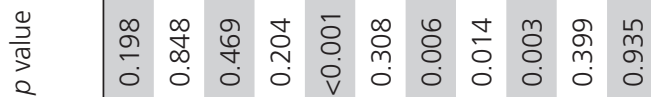

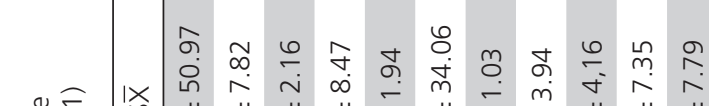

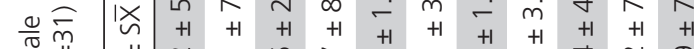

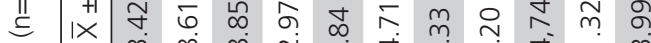

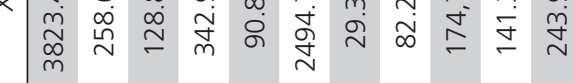

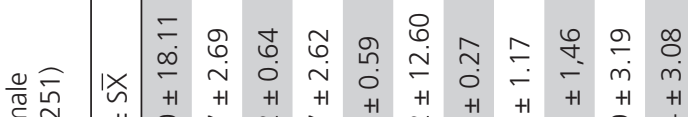

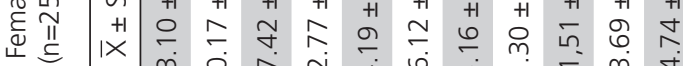

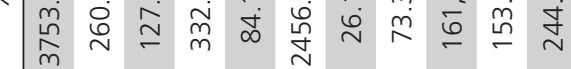

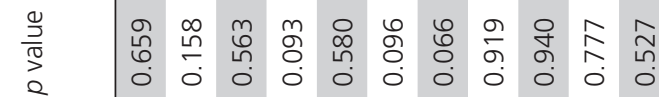

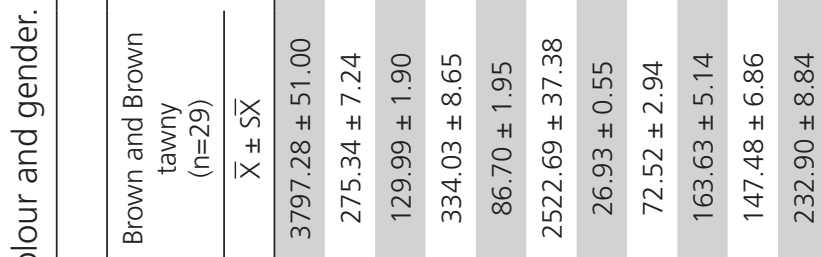

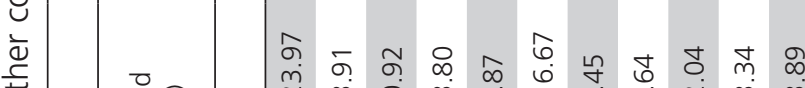

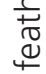

$\underset{\nabla}{\square}$ 尊

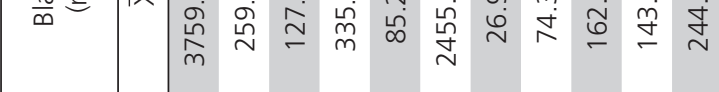

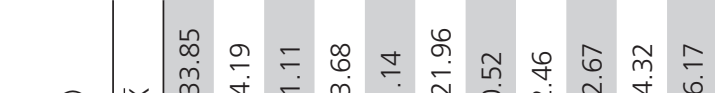

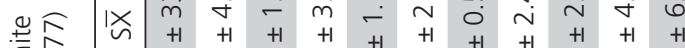

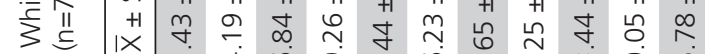

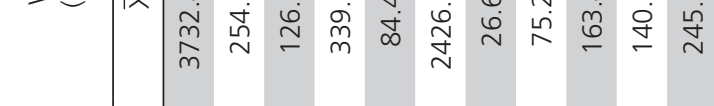

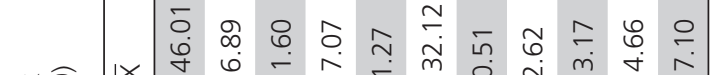

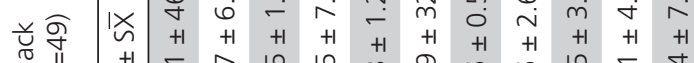
西

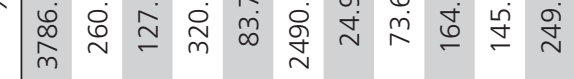

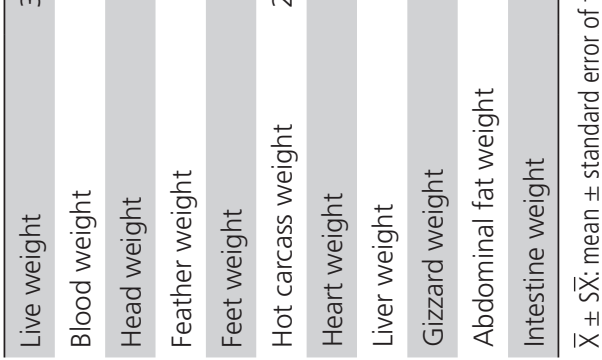

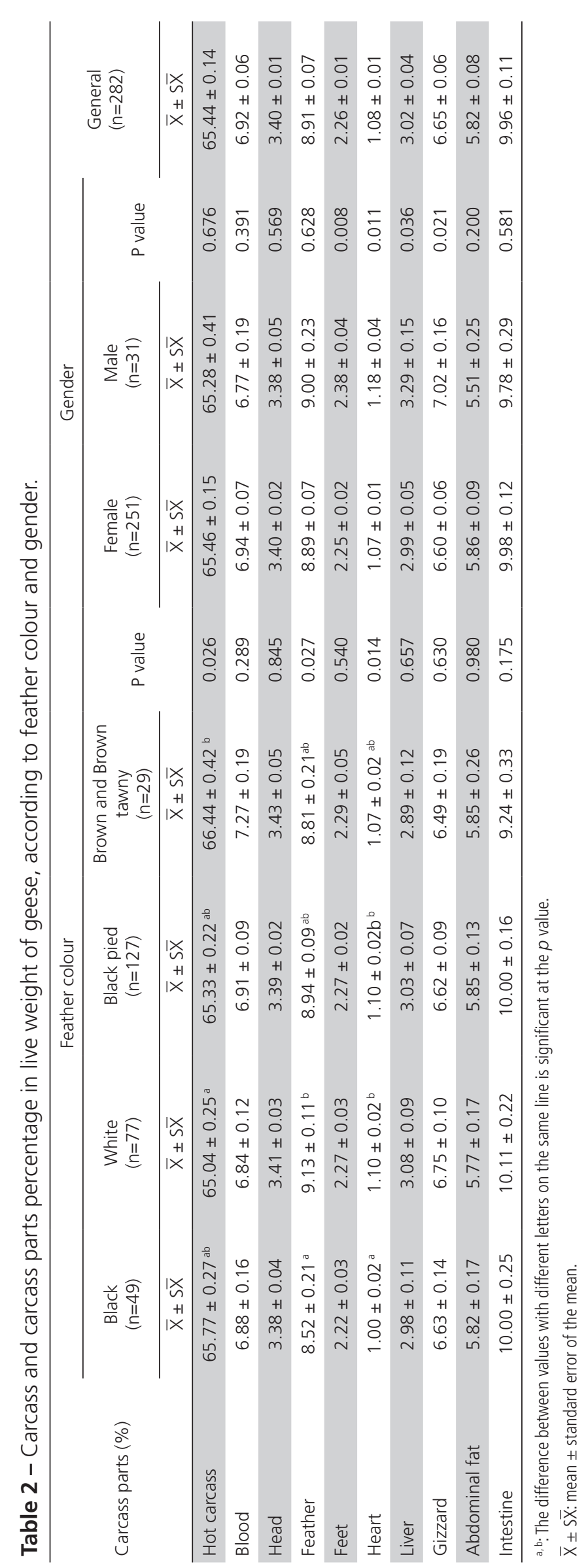


months of age and $3887 \mathrm{~g}$ at 18-20 months of age, and of $3799 \mathrm{~g}$ in males and $3649 \mathrm{~g}$ in females.

Kırmızıbayrak (2002), Tilki et al. (2004), Tilki et al. (2005), and Saatci et al. (2009) reported slaughter and carcass weight statistical differences between male and female geese in studies carried out in the Kars region. On the other hand, in subsequent studies, Kırmızıbayrak et al. (2011) and Saatci et al. (2011) did not find statistically significant differences in slaughter and carcass weights between male and female geese, as also observed in the present study. These differences among studies may be attributed to age at slaughter, genotype, and feeding practices.

The gender differences in feet, heart, liver and gizzard weights determined in the present study are also closely similar with those reported by Tilki et al. (2004) on feet, heart and liver weights, by Kırmızıbayrak et al. (2011) on blood and gizzard weights, and by Sarıca et al. (2015) on feet and heart weights when comparing male and female geese.

In the study of Saatci et al. (2009), the effect of different feather colours of geese on slaughter, head and feet weights was statistically significant, whereas blood, liver, and hot carcass, and cold carcass weights were not statistically influenced by feather colour. In a similar study, a significant effect of feather colour on abdominal fat weight was reported (Sarıca et al., 2015). In another study, goose feather colour had no effect on slaughter and carcass characteristics; however, statistically significant differences in the weights of carcass parts, such as breast, back and wing was detected (Yakan et al., 2012). In the present study, slaughter and carcass characteristics were not affected by feather colours. These findings were different those reported Saatci et al. (2009) and Sarica et al. (2015), but are consistent with the results of Yakan et al. (2012). Again, these differences may be due to bird age, genotype, and management practices among studies.

In geese, feather yield increase as body size increases (Kırmızıbayrak et al., 2016b). According to Saatci (2008), feather yield is positively correlated with live weight. Several authors (Tilki et al., 2005; Çelik \& Bozkurt, 2009; Kırmızıbayrak et al., 2011; Saatci et al., 2011; Kırmızıbayrak et al., 2016b) reported that average goose feather weight in Turkey was 164-638 g. In the study carried out in Kars province by Saatci (2008), feather colour influenced feather weight, with the highest average feather yield obtained in black and yellow feathered geese, while the lowest average feather yield was measured in white feathered geese.
Sarica et al. (2015), evaluating geese in the Yozgat province, Turkey, did not find any effect of feather colour on feather weight. In this study, although there was no statistical influence of feather colour $(p>0.05)$ on feather weight, the lowest feather weight value was determined was in black-feathered geese, while white-feathered geese had the highest value.

In the present study, statistically significant $(p<0.05)$ differences in hot carcass, feather and heart percentages in live weight among feather colour groups were determined, as well as in feet, heart, liver and gizzard yields between males and females $(p<0.05)$. Sarica et al. (2015), in a study conducted with geese of different feather colours, found significant feather, feet, and abdominal fat percentages differences among groups. Kırmızıbayrak et al. (2011) reported the influenced of gender on goose feet and gizzard yields. The findings obtained in the present study are consistent with these studies.

In conclusion, the results showed that feather colour did not influence the evaluated slaughter and carcass characteristics of geese reared under semi-intensive conditions in the province of Kars, Turkey, except for hot carcass, feather ratio and heart yields. In addition, higher feet, heart, liver and gizzard weights and yields were obtained in male compared with female geese.

\section{CONFLICT OF INTEREST}

The authors report no conflicts of interest.

\section{REFERENCES}

Castellini C, Berri C, Le Bihan-Duval E, Martino G. Qualitative attributes and consumer perception of organic and free-range poultry meat. World's Poultry Science Journal 2008;64:500-512.

Çelik B, Bozkurt Z. Slaughter and carcass traits of native geese reared in Muş province. Lucrări Stiințifice Zootehnieşi Biotehnologii 2009;49:423-428.

Demir P, Kırmızıbayrak T, Yazıcı K. Socio-economic importance of goose breeding. Ankara Üniversitesi Veteriner Fakültesi Dergisi 2013;60:254258.

FAO. Live animals. Rome: Faostat; 2014 [cited 2017 jul. 01]. Available from: http://www.fao.org/faostat/en/\#data/QA.

Kırmızıbayrak T. Kars ilindeki kaz yetiştiriciliği ve ekonomik önemi. Çiftlik Dergisi 2001;206:62-64.

Kırmızıbayrak T. Slaughter and carcass traits of native geese reared in local breeder conditions in Kars. Turkish Journal of Veterinary and Animal Sciences 2002;26:667-670.

Kırmızıbayrak T, Önk K, Yazıcı K. Effects of age and sex on slaughtering and carcass characteristics of Turkish native geese reared in free range production conditions in Kars province. Kafkas Üniversitesi Veteriner Fakültesi Dergisi 2011;17:41-45. 
Kırmızıbayrak T, Boğa Kuru B, Yazıcı K. Yield and traits of goose eggs and hatcability traits. Turkiye Klinikleri Journal of Reproduction and Artificial Insemination-Special Topics 2016a;2:42-47.

Kırmızıbayrak T, Boğa Kuru B, Yazıcı K. Feather yield and traits of geese, and feather production in the World and Turkey. Turkiye Klinikleri Journal of Reproduction and Artificial Insemination-Special Topics 2016b;2:48-55.

Saatci M. Effects of age, sex, feather colour, body measurements and body weight on down and feather yield in native Turkish geese. Turkish Journal of Veterinary and Animal Sciences 2008;32:293-297.

Saatci M, Tilki M, Kaya I, Kırmızıbayrak T. Effect of fattening length, feather colour and sex on some traits in native Turkish geese. II. Carcass traits. Archiv Fur Geflugelkunde 2009;73:61-66.

Saatci M, Arslan C, Ünal Y, Tilki M, Aksoy AR. Effect of fattening length, sex and feather colour on growth and fattening performance in native Turkish geese. Eurasian Journal of Veterinary Sciences 2011;27:183189.
Sarıca M, Boz MA, Yamak US. Slaughter and carcass traits of white and multicolor geese reared in backyard in Yozgat. Turkish Journal of Agriculture - Food Science and Technology 2015;3:142-147.

Tilki M, Saatci M, Kırmızıbayrak T, Aksoy AR. Slaughter and carcass traits of geese raised in Boğazköy-Kars. Kafkas Üniversitesi Veteriner Fakültesi Dergisi 2004;10:143-146.

Tilki M, Saatci M, Kırmızıbayrak T, Aksoy AR. Effect of age on growth and carcass composition of Turkish native geese. Archiv Fur Geflugelkunde 2005;69:77-83.

TÜIK. Son Yayımlanan Haber Bültenleri; 2016 [cited 2017 feb 10]. Available from: http://www.tuik.gov.tr/Start.do.

Yakan A, Aksu Elmalı D, Elmalı M, Şahin T, Motor S, Can Y. Carcass and meat quality characteristics of white and multicolor geese under local breeder conditions. Kafkas Üniversitesi Veteriner Fakültesi Dergisi 2012;18:663-672 
